\title{
The Masoretic Notes in Three Commentaries Attributed to Rashi
}

\author{
Lea Himmelfarb \\ Bar-Ilan University*
}

Using the Mikra'ot Gedolot 'Haketer' version of Rashi's commentary on three Biblical passages (Deuteronomy 33:23, Isaiah 14:11 and Ezekiel 17:9) the author reviews the textual version of the commentaries' transmission from medieval manuscripts to print editions. Addressing their meaning and adducing the masoretic notes that the Meyuhas may have used in making additions, the author demonstrates that these later additions have generated erroneous attributions to Rashi's original commentaries. In the first two cases, the commentator employs the Masorah note as an interpretive tool. Firstly, he cites the Masorah Magna to support his claim that this unusual form of (Deut 33:23) is indeed in the imperative. Secondly, the commentator adduces from a masoretic note that the word נְבדיל (Isa 14:11), which occurs twice in the Bible in this form has two meanings. In the third case, the Masorah note had no interpretive agenda; it merely pointed out that all the letters of the Hebrew alphabet appear in Ezekiel 17:9.

Keywords: Masorah; Rashi; Mikra'ot Gedolot 'Haketer'; Biblical Commentary; Deuteronomy 33:23; Isaiah 14:11; Ezekiel 17:9.

Notas Masoréticas en tRes COMENTARIOS ATRIBUidos a Raší.- Partiendo de la versión del comentario de Raší a tres pasajes bíblicos (De 33:23, Is 14:11 y Ez 17:9) contenida en las Mikra'ot Gedolot 'Haketer', la autora revisa la transmisión del texto de dichos comentarios desde los manuscritos medievales a las ediciones impresas. Mediante el análisis de su significado y aduciendo las notas masoréticas contenidas en las adiciones, y que había sido atribuido (Meyuḥas) a Raší, la autora demuestra que dicha atribución puede ser errónea y no corresponde a los comentarios originales de este autor. En los dos primeros pasajes estudiados, se muestra cómo el comentarista había empleado la nota de la masora como instrumento de interpretación. En primer lugar, cita la Masora Magna para apoyar su afirmación de que la forma inusual de ירָָָּּׁ (De 33:23) estuviera en imperativo. En segundo lugar, partiendo de una nota masorética, el comentarista aducía que la palabra נִבְְליך (Is 14:11), que aparece en esta forma dentro de la Biblia en dos ocasiones, puede tener dos significados. En el tercer caso, la nota masorética carece de contenido interpretativo, y señala, en realidad, el hecho de que todas las letras del alefato aparezcan en Ez 17:9.

\footnotetext{
${ }^{*}$ leahimm1@gmail.com
} 
Palabras Clave: masora; Raší; Mikra'ot Gedolot 'Haketer'; comentario bíblico; Deuteronomio 33:23; Isaías 14:11; Ezequiel 17:9.

The purpose of the Masorah is to accurately preserve the Biblical text and its wording. Primarily interested in exceptional and rare phenomena, the Masorah records the number of such occurrences, after counting and summarizing them. Although the Masorah notes relate to textual issues, Rashi ascribes interpretive significance to them and utilizes them in his commentaries on the Hebrew Bible ${ }^{1}$ in twenty cases. ${ }^{2}$ In this study, I will examine three instances in which the Masorah was cited in Rashi's commentary, but according to Mikra'ot Gedolot 'Haketer' (hereinafter: $M G H)^{3}$ this attribution to Rashi is incorrect.

The popularity of Rashi's commentary on the Bible and its widespread dissemination resulted in many errors being introduced into both the manuscript and print versions. In addition to the copyists and printers' errors, Rashi's commentary is unique both in that Rashi himself revised his commentary and in that others added segments which Rashi definitely did not write. The latter phenomenon already commenced with Rashi's devoted disciples, who added explanations on Rashi's comments or introduced

${ }^{1}$ For studies on the interpretive role of the Masorah notes embedded in Rashi's commentary, see L. Himmelfarb, "The Masoretic Notes in Rashi's Commentary on the Bible and Their Relation to His Commentary" [heb.], in S. VARGON et al. (eds.), Studies in Bible and Exegesis - Presented to Menachem Cohen VII (Ramat-Gan 2005), 41-60; EADEM, "On Rashi's Use of the Masorah Notes in His Commentary on the Bible" [heb.], Shnaton - An Annual for Biblical and Ancient Near Eastern Studies 15 (Jerusalem 2005), 167184. For studies on Rashi's use of the Masorah notes to validate the Biblical text and its correct pronunciation, see L. Himmelfarb, "Masorah Notes as a Tool for the Preservation of the Biblical Text in Rashi's Commentary on the Bible" [heb.], in S. VARGON, A. Frisch and M. Rachimi (eds.), Studies in Bible and Exegesis - Presented to Elazar Touitou VIII (Ramat-Gan 2008), 231-244.

${ }^{2}$ I used the Keter CD-ROM which is an electronic version of the Revised and Augmented Scientific Edition of Mikra'ot Gedolot 'Haketer' based on the Aleppo Codex and Early Medieval MSS, ed. M. CoHEN (Ramat Gan 1996). Unless otherwise specified, all commentaries are cited from the Keter CD-ROM. I wish to thank the staff of the Mikra'ot Gedolot 'Haketer' Project of Bar-Ilan University, headed by Prof. Menachem Cohen, for the assistance extended to me.

${ }^{3}$ See infra notes 7, 34 and 60. 
interpretations not mentioned by him. Other additions were later incorporated into the manuscripts by those studying the commentary. During the processes of copying and editing the commentary, these additions made their way into the body of the commentary. ${ }^{4}$

I have chosen to privilege the $M G H$ edition because it cites the most accurate version of Rashi's commentary which "is dozens of times more qualitative than those [versions] found in the [other] extant editions that are replete with thousands of errors and corruptions." ${ }^{5}$ However it should be noted that the editorial policy of the $M G H$ is to include a large selection of additions, which are placed in square brackets so as to distinguish them from Rashi's actual commentary.

Be that as it may, in each one of the three cases, I will begin by commenting on the version of the additions -the text attributed to Rashi (hereinafter: Meyuhas) - that my investigation of the manuscript and printed versions of the commentary led me to. ${ }^{6}$ Then I will examine the interpretation offered by the Meyuhas attempting to discover how it differs from those offered by the Targumim and other biblical commentators. Finally, I will attempt to present the Masorah note (or one similar to it) that the commentary attributed to Rashi cites.

\footnotetext{
${ }^{4}$ Due to the enormous scope of this topic -"The Additions in Rashi's Commmentary"the discussion had to be limited, and we decided to focus primarily on the Masoretic notes mentioned in the additions. For a scholarly overview of the difficulties involved in determining Rashi's text and distinguishing the additions made to it, see M. CoHEN, "Introduction," MGH - Joshua-Judges (Ramat Gan 1996), 1*-99*, esp. 32*-42*, 84*85*; J. S. Penkower, "Rashi's Corrections to his Commentaries on Joshua and Kings" [heb.], in Studies in Bible and Exegesis - Presented to Elazar Touitou VIII (Ramat Gan 2008), 335-383; Y. Maori, "The Text of Rashi's Commentary on the Pentateuch: The Present State of Scholarship" [heb.], in A. Grossman and S. JAPHET (eds.), Rashi - The Man and His Work (Jerusalem 2008), vol. I, 63-97.

${ }^{5}$ M. CoHEN, "Introduction," MGH - Genesis, vol. I (Ramat Gan 2000), 11. Since we do not have an authoritative manuscript of Rashi's commentary written in the author's own hand, the staff of the Mikra'ot Gedolot 'Haketer' Project reviewed all the early manuscripts of Rashi's commentary on the Bible. After comparing them methodically, they chose the best one, both in terms of the nearly complete absence of additions and in terms of its overall quality. On editions that were considered to be scientific and were found to be inaccurate, see n. 37 .

${ }^{6}$ This investigation of the manuscripts was performed before $M G H$ was published.
} 


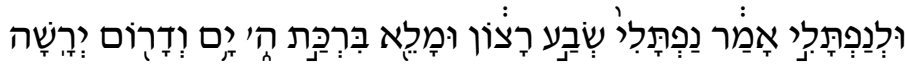

(Deuteronomy 33:23)

The Meyuhas makes the following addition:

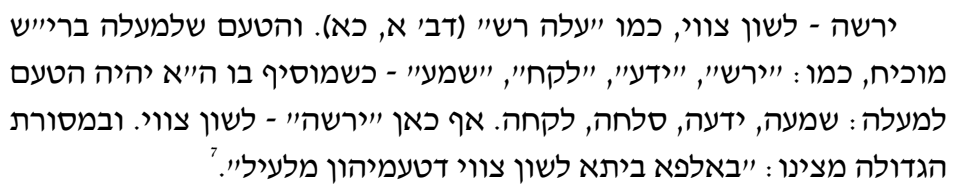

"עלה רש" (Deut 1:21). The stress that is penultimate on the resh proves this, as in [the ordinary imperative forms of] שמע, לקח, ידע, שעח, שמער, which take a penultimate

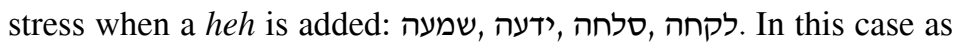
well ירשה is in the imperative form. And in the Masorah Magna we have found: "באלפא ביתא לשון צווי דטעמיהון מלעיל" ['an alphabetical list of imperative forms with penult stress']."

Having reviewed the manuscripts evidence, I also came to the conclusion that this interpretation should not be ascribed to Rashi. The entire passage is absent in MS Parma De Rossi 181 which is known for its accuracy, as it was used as the basis for the $M G H$ 's version of Rashi's commentary on Deuteronomy. The entire passage is found nowhere in the cohort of high quality manuscripts I examined, including, Vienna 23 and 24, Paris 48/49, and Cincinnati 51.'

${ }^{7}$ I would like to thank Dr. Yosef Peretz for providing me with the best version of Rashi's commentary on the word רשה that will eventually be published in the MGH Deuteronomy.

${ }^{8}$ I translated Rashi's commentary and compared this translation with M. RosenBAum and A. M. Silbermann et al. (eds.), Pentateuch... and Rashi's Commentary Translated into English - Deuteronomy [heb.] (Jerusalem 1973); A. J. Rosenberg, A New English Translation of Text, Rashi and Commentary (New-York 1988). All other translations in this article are entirely my own, unless otherwise indicated.

${ }^{9}$ While I did not review a vast number of manuscripts, the cohort I studied comprise those consulted in establishing the text of Rashi's Pentateuchal commentary in the $M G H$. 
One might speculate that the absence of this addition in MSS Vienna 23 and 24, which include additions to Rashi's commentary and are routinely understood to stem from R. Joseph Kara's manuscripts, indicates that the provenance of this addition is not Rashi's immediate circle.

This passage is cited in the version of Rashi's commentary found in MS Vatican 94 and MS Paris 155. However, it is difficult to establish the source of the addition to those manuscripts: Was it introduced by those learning or by those copying Rashi's commentary in the Middle Ages? These manuscripts of Rashi's commentary contain minute differences, ${ }^{10}$ which indicates that they probably do not stem from one single source.

The addition is also found in several print editions, for instance, in the first printed edition of Rashi's commentary " and in Mikra'ot Gedolot Venice. ${ }^{12}$ We may assume that the basis for this addition in the print versions was either one of the aforementioned manuscripts or another one like them.

This passage is cited in several critical editions, including Berliner's first edition, published in $1905 .{ }^{13}$ But Berliner, in his new edition, published in 1970, cited this interpretation in square brackets and noted that he did so to denote "the new version, which the majority attest to as the best and primary one." ${ }^{14}$ Berliner in a list of "names of books [...] cited in Rashi's commentary on the Pentateuch" that he compiled, includes the "Masorah Magna: Deuteronomy 33:23" (p. 428). Likewise, Chavel included this interpretation in his critical edition, and in his introduction, where he listed "the books that Rashi had seen and used," the final item listed was the Masorah Magna, and our verse was brought as an example. ${ }^{15}$

${ }^{10}$ For example, the words "imperative form" do not appear in MS Paris 155. In MS Vatican 94 instead of the phrase יהיה הטעם, the word employed is מנוגן.

${ }^{11}$ Rashi's Commentary on the Pentateuch [heb.]. First edition: Reggio di Calabria 1475, with an introduction by Y. Y. CoHEN (Jerusalem 1969).

${ }^{12}$ Mikra'ot Gedolot, Jacob ben Hayyim ibn Adoniyahu edition (Jerusalem 1972, repr. ed., Venice 1524-1526) [hereinafter: $M K G$ Venice].

${ }^{13}$ A. Berliner, Raši 'al ha-Torah: 'im beur Zekor le-Avraham (Frankfurt/M 1905).

${ }^{14}$ A. Berliner, Rashi's Commentary on the Pentateuch [heb.] (Jerusalem 1983²), "Introduction," XV.

${ }^{15}$ C. D. Chavel, Rashi's Commentary on the Pentateuch [heb.] (Jerusalem 1983²), “Introduction,” p. 9 (n. 39). In M. H. Harraz, Lešon Hayyim (Jerusalem 1970) only the last sentence, explicitly mentioning the Masorah, is missing. 
As for the commentary's contents, as is Rashi's wont, the Meyuhas

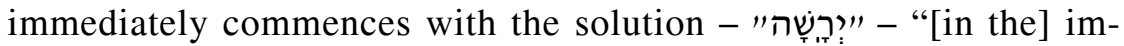
perative form" - and fails to explicate the difficulty posed by the biblical verse. In this case, the complication arises from determining the

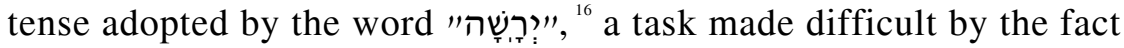
that when the word is pronounced with a penultimate stress, this may be indicative of the past tense, like "שְָׁמָָָה" (Amos 1:11), but given the context of the verse, this cannot be the case, since the land has yet to be inherited. ${ }^{17}$ Instead, like other words with penultimate stresses,

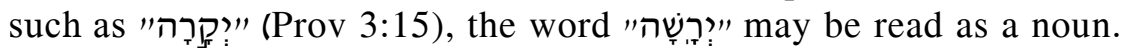
Indeed, Bekhor Shor, ${ }^{18}$ Heidenheim, ${ }^{19}$ and the NJB ("the West and the South are to be his domain") ${ }^{20}$ adopted such as reading.

The commentators may have also entertained the possibility that "רָָָָּׁה" denotes the future, a promise of the inheritance to come: thus, in the early Targumim including the Septuagint, the Samaritan Pentateuch, and Targum Onkelos, and in modern translations, including the NIV, "he will inherit southward to the lake," and the BBE, "the sea and its fishes will be his." ${ }^{21} \mathrm{R}$. Sa'adiah Gaon, ${ }^{22}$ Craigie, ${ }^{23}$ and Steinberg, in his dictionary, ${ }^{24}$ also adopt this approach.

The Meyuhas explained that "רָָָָּּה": is in the imperative form, so did Luzzatto, ${ }^{25}$ and several biblical lexicons, including Gesenius ${ }^{26}$ and the

${ }^{16}$ For the various homiletical exegeses based on this unusual form, see, for instance, the Tosafists on the Babylonian Talmud, Berakot 51a, s.v. zokeh ki-šene 'olamot and Naḥmanides, ad locum.

${ }^{17}$ So states H. Ben Bezalel, Be 'er Mayim Hayim (London 1964).

${ }^{18}$ Rabbi J. Bekhor Shor's Commentaries on the Pentateuch [heb.], ed. Y. Nevo (Jerusalem 1994).

${ }^{19}$ Z. W. HeIDENHEIM, Havanat ha-Mikra (Vilnius 1888).

${ }^{20}[\mathrm{NJB}=$ New Jerusalem Bible (1985)]. Bible Works 6 was my source for the English translations.

${ }^{21}$ [NIV= New International Version (1984); BBE= Bible in Basic English (1949)].

${ }^{22}$ Peruš Rabbenu Sa'adiah Gaon 'al ha-Torah, ed. Y. KAPAKH (Jerusalem 2004).

${ }^{23}$ P. C. CRaIgIE, The Book of Deuteronomy (NICOT) (Grand Rapids 1976), n. 42.

${ }^{24}$ J. SteinBerg, Milon ha-Tanak (Tel-Aviv 1982), p. 347.

${ }^{25}$ Š. D. Luzzatto, Commentary on the Pentateuch [heb.] (Tel Aviv 1992 [Padua 1871]).

${ }^{26}$ E. Kautzsch, Gesenius' Hebrew Grammar, revised by A. E. Cowley (Oxford $1910^{2}$ ), p. $133 \S 48$ i. 
BDB. ${ }^{27}$ Additionally, over ten English Bible translations render the verse in a similar manner; JPS, for instance, chose "possess thou the sea and the south."

We must not forget that grammatical matters which are considered straight forward today were not so in the eras of Rashi and of the author of the commentary attributed to Rashi; therefore, he provided an explanation for his grammatical insight, adducing proof from the location of the stress. The imperative form always takes an ultimate stress (ירשי, ירשו); however, in this instance, the stress is penultimate because in a normal, second person imperative, the stress falls on the 'ayin ha-po'al (second radical), as in and the stress remains in the same place even when the letter is appended to the imperative: שמעה, ידעה, סלחה, לקחה.

As for the examples adduced by the commentary attributed to Rashi, four verbs were included in each group; however, ירש was not included in the second group and סלחה was omitted from the first. Even though the other three verbs are mentioned in both groups, the parallel between the two groups is lost because the verbs are arranged in different orders. Furthermore, while two of these verbs do appear in the Bible in the im-

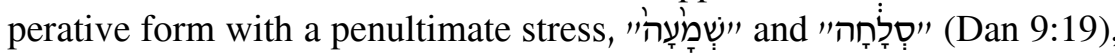
the other two examples, לקחה מדעה, only appear in the past tense: the

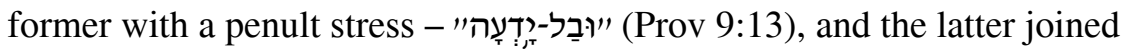

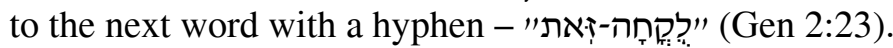

At the end of this passage, the Meyuhas brought the Masorah Magna to support his claim that this unusual form of ירשה is indeed in the imperative. The word ירשה is including in the list אלפא ביתא לשון ציווי דטעמיה wלהות" , that is to say an alphabetical list of words with imperative forms and penult stresses.

Which particular Masorah note (or one similar to it) did the commentator whose work is attributed to Rashi base his commentary on? He declared that the Masorah note is to be found in the Masorah Magna, that is currently known as $O \underline{k} l a h v e-O \underline{k} l a h$. Indeed, Ehrentreu ${ }^{28}$ has already

${ }^{27}[\mathrm{BDB}=\mathrm{F}$. Brown, S. R. Driver \& C. A. Briggs, A Hebrew and English Lexicon of the Old Testament (Oxford 1907)]. While KBL [= L. KoHLER \& W. BAUMGarTner, Lexicon in Veteris Testamenti libros (Leiden 1958)] also describes the word as in the imperative, it follows this with a question mark.

${ }^{28}$ E. Ehrentreu, Untersuchungen über die Massora (Hannover 1925), esp. p. 128. 
designated a particular list in $O \underline{k} l a h v e-O \underline{k} l a h^{29}$ as the source for this note in Rashi:"'א"ב מן חד וחד בטעמי לעיל ולית וסימני",', meaning an alphabetical list of unique words with penult stresses and their identifying quotes are... However, one could argue that the heading in $O \underline{k} l a h$ ve-Oklah, as well as the title of other lists, such as that in Frensdorff ,לעיל וקמץ לפניה משמשין ה' בסוף תיבותא" [an alphabetical list of unique words with penult stresses and at the end of the verse occurs a kames following by a heh.] differ from the version cited by the Meyuhas. Indeed, I have not found any Masorah note identical to that cited in the commentary attributed to Rashi, and it seems that the commentator reworked the original heading, either based on the text of a Masorah note in his possession or based on a note he remembered having once seen; in either case, he added the interpretive component of "[in the] imperative form" to the

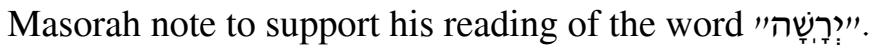

Whether or not the Masorah list can provide proof that "רָָָּּ" occurs in the imperative form is a question that arises not only from the version of the heading found in the commentary attributed to Rashi but also from a careful inspection of the list's components. The list in Oklah ve-Oklah. contains forty items, comprised of twenty-six verbs and fourteen nouns:

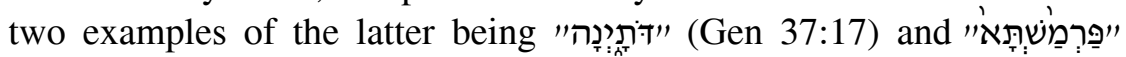
(Esth 9:9). The list of verbs is comprised of sixteen verbs in the third per-

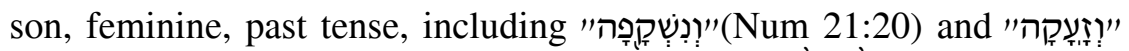
2) Sam 13:19); seven cohortative verbs, including "אָנוּסָּ" (Exod 14:15)

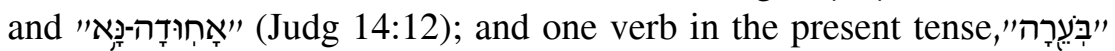

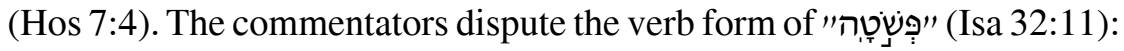
Rashi understanding it to be in the infinitive, and R. Eliezer of Beaugency arguing that it is in the imperative. Thus, only one item in the list is un-

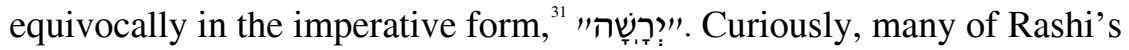

${ }^{29}$ Sefer Okllah ve-Oklah, S. FRENSDORFF edition (Hannover 1864, repr. New York 1972), list 32. In the edition by F. Díaz-Esteban, Sefer Oklah we-Oklah (Madrid 1975), list 33 .

${ }^{30}$ S. Frensdorff, The Massorah Magna, with a Prolegomenon by G. E. WeIL (New York 1968, first printed Hannover 1876), p. 328, letter heh.

${ }^{31}$ It seems that A. Berliner's comment (Raši 'al ha-Torah) that "the words 'in imperative form' are missing from the Masorah" (p. 421, n. 20) was not a result of his having checked the list, but rather a result of his having seen a version of the Masorah note found in, for instance, the Mikra'ot Gedolot, 'Am 'Olam (Jerusalem 1961) [hereinafter: 
commentators address "his" commentary on this verse; ${ }^{32}$ however, most entirely ignore the matter of the Masorah. ${ }^{33}$

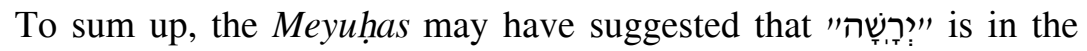
imperative tense in order to reject another possible interpretation. The commentator neither chose his examples carefully nor took care to cite them in their proper order. So while the Meyuhas did adduce a Masorah note to support his lone interpretation, he misused and misrepresented the Masorah, for I have not managed to find even one Masorah note that contains the unit לשון צווי 'imperative form' in its heading. Furthermore, even those notes that contain similar lists are comprised of examples not in the imperative, except for "ירָָָּהָ", the subject of our discussion.

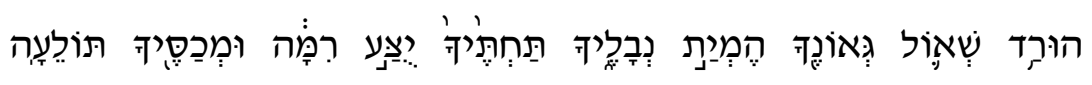

(Isaiah14:11)

Rashi comments המיית נבליך - נבלים וכנורות שהיו מזמרים לפניך The harps and lyres that used to play before you'. The Meyuhas in his addition to Rashi's commentary offers:

MKG 'Am 'Olam], (Final Masorah, Ma'areket 'Ot Heh, p. 15), also cited in FrENSDORFF, The Massorah Magna.

${ }^{32}$ See, for instance, Sefer Dikduk Raši...mi-Kadmon Eḥad, published by Y. Y. Septimus (1988); Y. E. Auerbach, Sefer Dikduke Raši Kolel Be’er Rehovot (Józefów 1878, repr. 1967); Y. L. KARINsKI, Minhat Yehudah, in Devarim 'im Peruš Ibn 'Ezra 'Mehokeke Yehudah' (Jerusalem 1971); Harraz, Lešon Hayyim, p. 166; BezAlel, Be'er Mayim Hayim.

${ }^{33}$ Except for BerLiner, Raši 'al ha-Torah and S. P. Gelbard's Li-Fešuto šel Raši (Jerusalem 1980), p. 275, n. 1, who do mention the Masorah Magna, but refer to it as "the detailed lists of the Masoretes, which were inscribed in the margins of the folio in the manuscripts of the Hebrew Bible," even though the term 'Masorah Magna' used by the commentary attributed to Rashi designates the list in $O \underline{k} l a h$ ve-O $\underline{k} l a h$ or another similar list found in the Final Masorah of the Mikra'ot Gedolot. CHAVEL, Rashi's Commentary on the Pentateuch', also errs in explaining that the term 'Masorah Magna' in Rashi refers to a work that "comments on and supplements the Masorah Parva" (p. x, n. 39). 


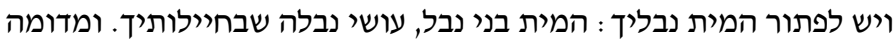

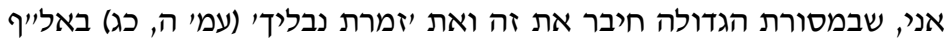

בי"ת של שתי לשונסת הגותותי.

'And המית נבליךshould be interpreted 'the strains of the scoundrels, those who do evil among your soldiers.' And it probably 'seems to me that the Masorah Magna joined this and ' (Amos 5:23) in an alphabetical [list] of [two equal words] with two meanings'.

This version of these interpretations was established by the author of the Mikra'ot Gedolot 'Haketer'. A cursory reading of Rashi's interpretation quickly reveals that the sub verbum "המיית" differs from our version of the biblical text. Indeed, while this version is found in the manuscripts, the printed editions (including, $M K G$ Venice, MKG Warsaw and its successors - all the popular versions of the Mikra'ot Gedolot [Pardess and 'Am 'Olam $])^{35}$ and even Maarsen's edition, which is considered a critical one, ${ }^{36}$ record the biblical text as "המית', in light of the printers' decision to emend every version found in manuscript form so that it would conform with the masoretic text. ${ }^{37}$ The Meyuhas in his addition to Rashi's commentary records the sub verbum "המית נבליך" as our version of the biblical text.

In the print editions there is no difference between Rashi's commentary and the commentary attributed to Rashi, neither in $M K G$ Venice nor in $M K G$ Warsaw and its successors. ${ }^{38}$

${ }^{34}$ MGH - Isaiah (Ramat Gan 1996).

${ }^{35}$ MKG Venice, Mikra'ot Gedolot Warsaw (Warsaw 1860-1867) [hereinafter: $M K G$ Warsaw]; Mikra'ot Gedolot, Pardess (Tel Aviv 1962) [hereinafter: $M K G$ Pardess]; $M K G$ 'Am 'Olam.

${ }^{36}$ Peruš R. Šelomo Yiṣ̣haki le-Yišayahu, ed. MaArsen, Paršan-data, pt. 2 (Hague 1935, repr. ed. Jerusalem 1972).

${ }^{37}$ On this phenomenon of emending divergent biblical versions so that they comply with the accepted masoretic text, see M. CoHEN, "Introduction," MGH - Genesis, vol. II (Ramat Gan 1999), 7-8: "Even the scientific editors of the commentary by Rashi, such as Berliner and Maarsen [...] also adapted the variant Biblical versions to the MT [...] and also attempted to emend the thousands of variants of plene and deficient spelling that are dispersed throughout the commentary," p. 7; IDEM, MGH - Kings (Ramat Gan 1995), p. 8.

${ }^{38}$ In the Maarsen edition the commentary attributed to Rashi is brought in a footnote (p. 42, note on 1. 1). Rosenberg also remarked (in a footnote) that in certain manuscripts the commentary attributed to Rashi does not appear. 


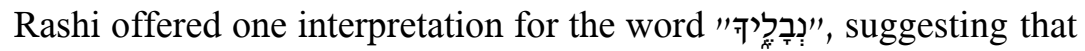
it denotes a musical instrument. This understanding was also adopted by the early Targumim - the Septuagint and Pseudo-Jonathan; by modern translations - NJPS, RSV, NEB, $\mathrm{AV}^{39}$; by biblical lexicons - BDB and $\mathrm{KBL}$; and similarly by a long list of medieval commentators $-\mathrm{R}$. Joseph Kara, R. Eliezer of Beaugency, Radak, R. Joseph Ibn Kaspi, Abarbanel ${ }^{40}$ - and of modern commentators: Krauss, ${ }^{41}$ Ehrlich, ${ }^{42}$ Hakham, ${ }^{43}$ Gray, ${ }^{44}$ Childs, ${ }^{45}$ and by Bauer. ${ }^{46}$

Professor Menachem Cohen, the editor of $M G H$, was well aware that "the reader might come upon the many additions to the commentary on Isaiah" and therefore he decided to "place the additions in square brackets to differentiate them from the original." 47

The Meyuhas in his addition to Rashi's commentary offers a com-

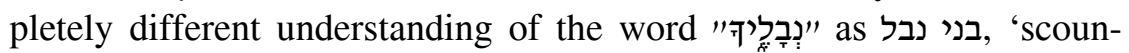
drels.' This commentary opens with the declaration that "המית נבליך "scoun " should be interpreted - openly asserting its preference for its own interpretation over the other interpretation offered by Rashi. ${ }^{48}$ Furthermore, the Meyuhas adduces support for his interpretation from the Masorah. He may privilege his interpretation precisely because of the support offered it by the Masorah, to which he ascribes interpretive weight. The proof that

${ }^{39}$ [NJPS= New Jewish Publication Society Version (1985); RSV= Revised Standard Version (1952); $\mathrm{NEB}=$ The New English Bible (1970); AV= American Standard Version (1901)].

${ }^{40}$ I. Abarbanel, Commentary on Later Prophets [heb.] (Tel-Aviv 1960).

${ }^{41}$ S. Krauss, Nevi'im, in Torah, Nevi'im u-Ketuvim 'im peruš mada 'i, ed. A. Kahana [heb.] (Jerusalem 1969).

${ }^{42}$ A. Ehrlich, Mikra Kifšuto - Divre Nevuah ['The Bible according to Its Literal Meaning'] (New York 1969).

${ }^{43}$ A. Haknam, Sefer Yešayahu 'im Peruš Da 'at Miqra' (Jerusalem 1979).

${ }^{44}$ G. B. GraY, The Book of Isaiah (ICC), vol. I:1-27 (Edinburgh 1912), p. 248.

${ }^{45}$ B. S. ChILds, Isaiah (OTL) (Kentucky 2000), p. 119.

${ }^{46}$ B. BAUER, "Neginah ve-Zimrah," in Encyclopaedya Mikra'it (Jerusalem 1968), V, p. 769.

47 "Introduction," MGH - Isaiah, p. 10.

${ }^{48}$ This, in contrast to Rosenberg's translation (A new English translation of text): "It is also possible to interpret." 
he adduces from the Masorah is a note commenting that the word "נְבְלָיך" (which only occurs twice in the Bible in this form) has two meanings (שתי (לשונות), that is to say, each time it appears it has a different meaning. A though it should be noted that even the Meyuhas circumscribes its reliance on the Masorah as a proof by explicitly stating, "And it probably seems to me that in the Masorah Magna..." Indeed, there seems to be some doubt

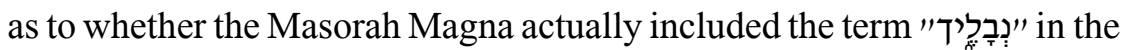
alphabetical list containing words with "two meanings." This doubt may have arisen because the commentator did not have the Masorah text in front of him, ${ }^{49}$ either because he did not have access to the Masorah text (as Ehrentreu argues) ${ }^{50}$ or because he could not check the Masorah text at the time he was writing (as Blau argues). ${ }^{51}$

A comparison of the way in which this Masorah is cited by the Meyuhas in the commentary on "בְבְביָ" and the way in which Rashi adduces the same Masorah in his interpretation of the word "שִירֶי"(Ps 42:9) is instructive. In contrast, to the hesitant tone the Meyuhas adopts here, ('And it probably seems to me'), which may mean that he only remembered the Masorah note, Rashi confidently asserts, וזו למדתי - ('I learned this from the Masorah Magna'), which implies that Rashi had arrived at his interpretation in tandem with (and as a result of) his careful study of the Masorah note in his possession. ${ }^{52}$

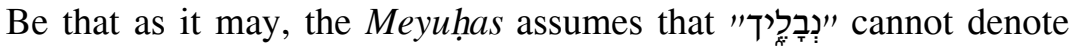
a musical instrument because each one of the pair of נבליך homonyms

${ }^{49}$ It is unlikely that the omission of the word נבליך from some lists has anything to do with this, for instance, in the list of pairs of homonyms - תרין בתרין לשנין - found in MS Cairo (D. Lions, The Cumulative Masora - Text, Form and Transmission...in the Cairo Prophets Codex (Beer Sheva 1999) we did not find נבליך.

${ }^{50}$ Untersuchungen über die Massora, p. 128.

${ }^{51}$ L. Blau, "Zur Massora," Studies in Jewish Bibliography... in Memory of A. S. Freidu (Farnborough 1969 [phot. ed. New York 1929]), 431-462, 451-457, esp. p. 453.

${ }^{52}$ For a discussion of this example, see L. Himmelfarb, "On Some Discrepancies between Rashi's Commentary on the Talmud and His Commentary on the Bible," HUCA 75 (2004), 163-191. The question of what sequence Rashi wrote his Bible commentaries is irrelevant since the commentary on Isaiah was, as mentioned above, not written by Rashi. Anyway B. J. Gelles, Peshat and Derash in the Exegesis of Rashi (Leiden 1981) assumes that Rashi wrote his commentary on the Prophets before the Hagiographa (ibid., pp. 138-139).

SEFARAD, vol. 71:2, julio-diciembre 2011, págs. 247-263. ISSN: 0037-0894. doi: 10.3989/sefarad.011.008 


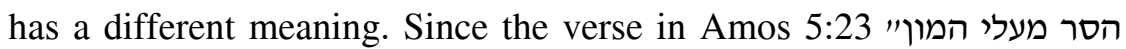
"שריך וזמרת נבליך לא אשמע "clearly refers to a musical instrument, it is reasonable to interpret the other occurrence to mean 'scoundrels' (בנב לני נבל). This interpretation is bolstered by the textual version found in the Isaiah Scroll discovered in Qumran Cave 1: נבלתך ${ }^{53}$ Tur-Sinai, ${ }^{54}$ Blenkinsopp, and (in a similar vein) Watts ${ }^{56}$ adopt this interpretation.

Luzzatto cited Rashi's interpretation at the beginning of his commentary. However, he did add: "and it would be possible to interpret [this] with the connotation of בָבָל ['a scoundrel']," and he cited the interpretation attributed to Rashi as Rashi's and produced the proof text from the Masoretes. This notwithstanding, he was reluctant to accept this interpretation, stating that "my mind has not warmed to his interpretation." ${ }^{57}$

Which Masorah note (or one similar to it) was the Meyuhas citing? The following title found in both editions of $O \underline{k} l a h v e-O \underline{k} l a h^{58}$ is similar in meaning to the note adduced by the commentator: .ותרין לישנין וסימ". an alphabetical [list] of two unique homonyms of two meanings and their identifying quotes. This alphabetical list contains

${ }^{53}$ See M. Goshen-GotTstein (ed.), The Book of Isaiah. The Hebrew University of Jerusalem edition (Jerusalem 1995).

${ }^{54}$ N. H. TuR-SinaI, Pešuto šel Mikra (Jerusalem 1962), vol. III.

${ }^{55}$ J. BLENKInSOPP, Isaiah 1-39 (AB) (New York 2000), p. 283.

${ }^{56}$ J. D. W. WATTS, Isaiah 1-33 (WBC) (Nashville 1985), p. 205.

${ }^{57}$ S. D. LuzZatto, Commentary on Isaiah (Tel-Aviv 1970 [Padua 1845-1897]). The author of the Bi'ur, V. MeIr, The Book of Isaiah translated... and interpreted [heb.] (Prague 1838), offered an interesting conflation of the two meanings: “...the prophet is referring to the statue that Nebuchadnezzar set up ... with regard to this as well he said המית נבליך, as the verse there (Dan 3:5) recounts העידנא די תשמעון קל קרנא וגון, and they said that now his statue is also despised and the sounds of music played during its worship will cease..." And in a similar vein, Y. Khul, Yalkut Me'am Lo'ez, completed

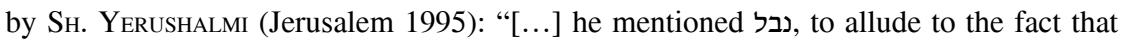
ניוול ('denigration'), and since he uses coarse speech, speaking high and mightily even about the Creator, he will reach the level where instead of hearing the strains of harps (המית הנבלים), he will hear the sounds of worms and maggots" (Isa, p. 171). The editor attributes this interpretation to anonymous commentators, without mentioning his sources. For the midrash that is foundational to this notion of a semantic connection between מנוול and, see R. I. ZAR, Masorah and Commentary [heb.]. Master's thesis, The Hebrew University of Jerusalem (Jerusalem 1999), p. 53.

${ }^{58}$ FrensDorfF, list 59; and Díaz Esteban, list 60. 
ninety-nine unique pairs, word pairs with the same form, but possessing a different meaning each time they are used. The seventy-seventh item is נבליך. We can see that the Meyuhas did not quote the Masorah note concerned with our case, but rather paraphrased it. As mentioned above, this Masorah note was also mentioned by Rashi in his commentary on the word "שיטירה": however, in no other case does Rashi cite this Masorah in his commentary to support his interpretation of other words on the list. ${ }^{59}$

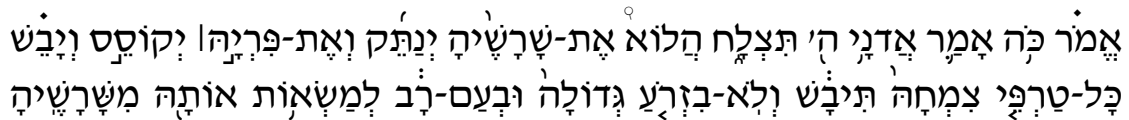

(Ezekiel 17:9)

The Meyuhas comments:

כל האלפא ביתא במקרא זה, ותמיה אני כי אינו נמנה במסורת.

'all the letters of the alphabet may be found in this biblical verse, and I am surprised that this is not enumerated in the Masorah. ${ }^{61}$

In Mikra'ot Gedolot 'Haketer', the editor places this passage in square brackets in order to distinguish it as an addition to Rashi's commentary. ${ }^{62}$ This passage does not appear in either MS Parma De Rossi 387, the manuscript chosen as the base text of $M G H$, or in MSS Vienna 23 and 24.

${ }^{59}$ Thus, for instance, Rashi interprets every one of the occurrences of the word pair ישעו, found in this Masorah list, differently: ישעו in Exod 5:9 is interpreted as "[let them not] think and speak..." while in 2 Sam 22:42, Rashi interprets it: "like: יפנה ('address' or 'turn to') [...]". Furthermore, Rashi even adds in his commentary on Exodus: "And one cannot say 'אל יפנו - אל ישעו"'. That is to say, even though Rashi is well aware that the word has different meanings in different places, he makes no mention of the Masorah note about "two meanings."

${ }^{60}$ MGH - Ezekiel (Ramat Gan 2000).

${ }^{61}$ A. J. Rosenberg, A New English Translation of Text - Ezekiel, Rashi and Commentary (New York 1999).

${ }^{62}$ On the additions in Rashi's commentary, see M. CoHEN, "Introduction,” [heb.] $M G H$ - Ezekiel, viii-ix. 
Luzzatto, in commenting on this verse, also notes that "in Rashi, [in] a manuscript on the Prophets in my possession the matter of the alphabet does not appear." ${ }^{63}$ In the printed editions (MKG Venice, MKG Warsaw) this passage is attributed to Rashi.

Usually we can only assert that Rashi himself did not write an addition if it is not found in any of the manuscripts containing Rashi's commentary. However, in our case, even though we only checked a few manuscripts we can make such a confident assertion because the ones we checked are known for their accuracy, as they were used as the basis for the $M G H$ 's version of Rashi's commentary on Ezekiel. Furthermore, Professor Jordan S. Penkower, who checked all sixty-one manuscripts, declared that various additions found in manuscript were not incorporated into the print versions and that approximately another two hundred additions not found in the manuscript were incorporated into the print versions of Ezekiel 1-39. ${ }^{65} \mathrm{We}$ will follow Penkower's suggestion that the additions were introduced by a single individual in the Middle Ages who made comments in the margins of a manuscript in his possession for his own personal use.

This led me to ponder what the source for this addition is, given that it appears in MKG Venice, but is not found in the manuscript versions. Apparently this manuscript with its additions did not influence the version in the other manuscripts, but it did wind up in the possession of Jacob ben Hayyim, the editor of MKG Venice, who used it in preparing his edition, without noticing that additions had been incorporated into the commentary. ${ }^{66}$

An examination of the contents of the addition -"all the letters of the alphabet may be found in this biblical verse, and I am surprised that this is not enumerated in the Masorah"- reveals that the passage has nothing to do with the interpretation of the verse. ${ }^{67}$ It merely testifies to the com-

${ }^{63}$ Š. D. Luzzatto, Peruše Šadal 'al Yirmiyahu, Yehezkel, Mišle, ve-Iyov (Lemberg 1876, repr. Jerusalem 1969).

${ }^{64}$ For a list of the sixty-one manuscripts, see J. S. Penkower "Rashi's Commentary on Ezekiel" [heb.] in Studies in Bible and Exegesis - Presented to Menachem Cohen VII (Ramat Gan 2005), 425-474.

${ }^{65}$ Ibid., 440-441.

${ }^{66} \mathrm{He}$ reaches this conclusion without discussing any of the additions addressed in this article.

${ }^{67}$ On exegetical-homiletical notes dealing with the twenty-two letters of the Hebrew alphabet, see, for instance, R. Ya 'aqob ben Ašer, Peruš Ba'al Ha-Turim 'al ha-Torah, ed. 
mentator's interest in the Masorah and to his having been familiar with a Masorah list that enumerated verses containing the entire alphabet, but did not include our own. He noticed that our verse should have been included.

The Meyuhas may have referred to a Masorah note from the Masorah Magna similar to that printed in MKG Venice and in MKG Warsaw on Ezekiel 38:12. ${ }^{68}$ In this list the item "הלא כגעת רוח הקדים" alludes to Ezek 17:10; however, this verse does not contain all the letters in the Hebrew alphabet. A comparison of this list with other ones suggests that an error transpired. For instance, in the Final Masorah in MS L and, likewise, in Ginsburg's masoretic compilation, ${ }^{69}$ instead of alluding to Ezek 17:10, the phrase - "אמר. כה אמר דתצלח" - alludes to the previous verse, Ezek 17:9, which does contain the entire Hebrew alphabet. ${ }^{70}$ The source of this error

Y. K. Reinitz (Bne Brak 1971): "This is what God has commanded. The [entire] alphabet appears in this verse in order to teach us that anyone who keeps the Torah, will receive his livelihood from the Holy One, blessed be He, without having to work hard, like those who consumed the manna" (Exod 16:16).

${ }^{68}$ The Masorah Parva notes, which are juxtaposed to the biblical text, only comment on a small portion of the verses; thus, for instance, in The Aleppo Codex - Provided with Masoretic Notes and Pointed by Aaron Ben Asher, edited with a Prolegomenon by M. Goshen-Gottstein [heb.], facs. ed. (Jerusalem 1976) = MS A, we find אית בפס' אלף" בית" (Josh 23:13), and in St. Petersburg, The National Library, MS Evr. I B 19a (facs. ed. Jerusalem 1971) = MS L and in the Sassoon Codex 507 (facs. ed. Copenhagen 1982) we find "כו פסוק אית בהון אלף בית" (Exod 16:16). Therefore we need not be surprised at the note's absence in other places.

${ }^{69}$ C. D. Ginsburg, The Massorah Compiled from Manuscripts (New York 1975 [London 1880-1905], repr., with a Prolegomenon... Table of Contents by A. Dotan], vol. III, p. 291.

${ }^{70}$ Luzzatto (Peruše Šadal 'al Yirmiyahu, Yehezkel, Mišle, ve-Iyov) already noted this, and his remarks are cited by Y. Ts. Moscowitz, Sefer Yehezkel 'im Peruš Da 'at Miqra' (Jerusalem 1985), n. 21c. According to Moscowitz, the list Luzzatto refers to "appears in the book of Deuteronomy 4:34 (או הנסה אלהים'), which is the first [example] of this kind of verse"; however, we could not find a Masorah Magna note on this verse, either in $M S L$ or in $M K G$ Venice and $M K G$ Warsaw. Furthermore, this verse is actually the second one of its kind, as Exod 16:16 precedes it ("זה הדבר אשר צוה לקטו ממנו"). We should also note that a graphical error probably befell in $M K G$ Venice's Final Masorah, Ma'areket 'Ot 'Alef:"כ"כ"ו פסוק' אית בהון כל הא"ב סימ' נמסר ביחזקאל סי" ל" and refers to Ezekiel chapter 31; but it should be Ezekiel chapter 38, as he correctly notes in the Masorah Magna on Esther 3:13. Likewise, M. TzuRIEL, Masoret Seyyag la-Torah (Bne Brak - Ashdod 1990). Even though Tzuriel declared at the beginning of his book 
may reside in the proximity of the two verses (although, alternatively, one could argue that the Meyuhas only discovered the additional verse due to their proximity) or in the similarity between words found in the first half of both verses - "תתצלח הלוא" (v. 9), "תצלח הלוא" (v. 10) - and in the

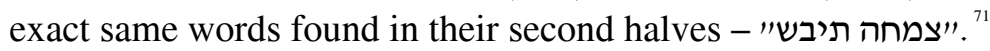

Recibido: $16 / 11 / 2010$

Aceptado: 07/11/2011

that "thousands of printers errors had been eliminated" from Jacob ben Hayyim's notes, he still copied the flawed list (p. 143).

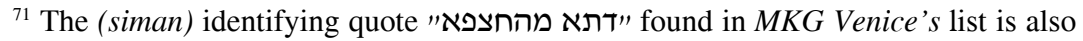
problematic. It seems to refer to Dan 2:15: "על-מה דתא מהחצפה",; however, this verse does not contain all the letters of the Hebrew alphabet and I did not find this identifying quote in any other list. The list in $M K G$ Venice is probably a corruption of the identifying quote "מלת מלכא מחצפה" found in several other lists, including the Final Masorah in MS $L$, which alludes to Dan 3:22. 